\title{
Listening Skills of College Freshmen of the Nueva Ecija University of Science and Technology
}

\section{Vladimir Tolentino Tamayo}

\begin{abstract}
The study evaluated the listening skills of college freshmen of the Nueva Ecija University of Science and Technology based on the five stages of listening with the use of descriptive-correlational research.

The researcher found out that most respondents, regardless of their profile, use their listening skill in listening to Tagalog music during the day through a medium (mostly mobile phones) accessible to them at all times. However, most respondents have only an average listening skill proved that they have a limited listening capability that needs to be addressed appropriately. Similarly, the respondents' academic performance could be affected if their listening skills would not be improved. Hence, intervention programs or activities that could enhance the listening competence of NEUST freshmen in learning the English language is needed and shall be regularly practiced.
\end{abstract}

Keywords-English language, evaluating, listening skills, receiving, remembering, responding and understanding.

\section{INTRODUCTION}

Effective academic communication means the demonstration of a certain degree of knowledge and expertise when participating in the most frequent communicative events inside the world of higher education. The author in [1] mentioned that "the discipline that studies the peculiarities and pedagogy of these events in English is called English for Academic Purposes (EAP)". A basic definition of this EAP might be the discipline that covers all the communicative skills necessary to study and excel in English. Today there are many references in the market, both on paper, books and even online, emphasizing the importance of these skills to become an effective communicator, and eventually, a successful student inside the university world.According to [2], "when a language is learned, specifically English, these four macro-skills (listening, speaking, reading, and writing skills proficiently) are needed for complete communication." The strategies and techniques include conversations, discussions, contextualized grammar exercises, listening, and interactive activities, readings, and literary appreciation. However, as stated by [3], the ability to use the grammar of a language, pronounce the sounds, and speak fluently may not be enough for effective communication. In the same vein, Fulcher continues, "the ability to communicate through speech is much more than the knowledge of the grammatical and phonological system of a language: unless learners understand the rules of speaking, they may at best appear rude or, at worse cause offense. In the same way, according to [4], "the key of the mind is through every word that is uttered. Through a specific language, an individual can express his thoughts and ideas".

Hearing and listening are two diverse part of communication. The author in [5]said that "hearing is the physiological process through which sound waves are collected through theear where auditory information is transmitted to the brain while listening while listening is the act of assigning meaning to what is heard." In the same way, [6] introduced a similar concept of hearing-listening difference; she defined listening as making an effort to hear something; to pay attention or heed while hearing isthe physiological process of the ear absorbing sound waves and transferring them along neural pathways to parts of the brain. Though hearing is necessary for listening, listening is much more than processing sound.The authors in [7] outlined listening skills as the ability to listen and comprehend oral communication.

On the other hand, [8]takes a profound meaning of listening skill wherein he stated that this skill is a state of mind that involves paying full and careful attention to the other person, avoiding premature judgment, reflecting understanding, clarifying information, summarizing and sharing. According to [9], "the ability to perform stemmed from the ability to listen to instructions." Listening is important for effective communication because 50 percent or more of the time spent on communication is spent in listening [10]. To assess the listening skills of an individual, there are five stages a sound must go through to determine that the oral message being transmitted has been successfully delivered. These stages are receiving, understanding, remembering, evaluating, and responding [11]. 
The above kinds of literature proved the importance of listening most importantly in the academe. Hence, the researcher, who is an English teacher, is concerned and believe that studying and evaluating the listening skills of his college freshman students is vital to fully understand their level of listening competence.

The study based its idea on the five stages of listening by [11]. Specifically, it aimed to describe the profile of the freshmen, their listening skills, and the relationships that exist between the profile and listening skills of the freshmen.

\section{METHODOLOGY}

The study used descriptive-correlational research design which [12] stated that "these methods include naturalistic observation, case studies, and surveys." It is employed to test the degree of relationship between two or more variables [13] as cited in [14].First, the profile variables of college freshmen were described. Second, the listening skills of learners were described. After which, a significant relationship between these two variables was looked into, as well as the relationship of the learners' listening skills in terms of receiving, understanding, remembering, evaluating and responding as related to their achievement in their English subjects.

The respondents were composed of college freshmen of theNEUST. Table 1 shows the frequency and percentage distribution of the respondents percourse.

Table 1. Distribution of Respondents

\begin{tabular}{lccc}
\hline \multicolumn{1}{c}{ Course } & N & n & \% \\
\hline Engineering & 38 & 8 & 2.54 \\
Nursing & 16 & 3 & .95 \\
Agriculture & 46 & 10 & 3.17 \\
Hotel and Restaurant Management & 120 & 25 & 7.94 \\
Criminology & 64 & 13 & 4.13 \\
Information Technology & 434 & 92 & 29.21 \\
Architecture & 12 & 3 & .95 \\
Industrial Technology & 123 & 26 & 8.25 \\
Education & 113 & 24 & 7.62 \\
Management and Business Technology & 526 & 111 & 35.24 \\
\hline
\end{tabular}

\section{Total} 1492

$315 \quad 100 \%$

The research instrument was personally conceptualized by the researcher, and the question items were derived from the classic song "Don't Cry Joni" by Conway Twitty with a length of 3 minutes and 40 seconds. The questionnaire was divided into two parts: Part I contains data regarding the profile of the respondents. The profile includes sex, course, language spoken at home, gadgets used, and programs watched or listened to; Part II contains questions derived from the song "Don't Cry, Joni." The questions were categorized according to the five listening stages, such as receiving, understanding, remembering, evaluating, and responding.

The first draft of the instrument was reviewed and consulted to an expert. In validating the instrument, dry-run involving the students who are not respondents of the study was undertaken. The pages of the questionnaire were detached from each other and were administered to the respondents' page by page and automatically collected from the respondents so that the whole content of the listening test would not be revealed to them. Every page of the questionnaire was given a time limit to maintain the quality of the listening test. After conducting the dry run, the questionnaire was once again consulted to expert for revision purposes. Afterward, ten scores of students from the dry run were sent to the statistician to determine if the scores obtained are reliable.

The specific statistical tools used in analyzing the data were as follows:

Profile variables of the students. The profile variables were analyzed and subjected to statistical treatment using frequency and percentage distribution. A Likert scale was used in determining the listening skills of college freshmen in terms of receiving, understanding, remembering, evaluating, and responding. The following rating scale was used to interpret the responses of the researcher about the listening skills of college freshmen. The same verbal interpretations were used in the total score of the listening skills of the respondents.

Table 2. Descriptors

\begin{tabular}{ccl}
$\begin{array}{c}\text { Range of } \\
\text { Score }\end{array}$ & $\begin{array}{c}\text { Verbal } \\
\text { Interpretation }\end{array}$ & \multicolumn{1}{c}{ Meaning } \\
\hline $0-7$ & Poor & did not answer the question correctly \\
$8-14$ & Fair & answered the question correctly with many errors \\
$15-21$ & Good & answered the question correctly with few errors \\
$22-28$ & Very Good & answered the question with minimal errors \\
$29-35$ & Excellent & answered the questions correctly and completely \\
\hline
\end{tabular}


The scores from Understanding Stage, Evaluating Stage, and Responding Stage were obtained using the rubrics below, which was personally formulated by the researcher.

\section{Listening Skills of College Freshmen of the NEUST}

Table 3. Essay Assessment Rubric

\begin{tabular}{llll}
\hline \multicolumn{1}{c}{ Spelling/Grammar } & \multicolumn{1}{c}{ Clarity } & \multicolumn{1}{c}{ Content } & \multicolumn{1}{c}{ Total } \\
(1) & \multicolumn{1}{c}{$(\mathbf{2})$} & \multicolumn{1}{c}{ (5) } \\
\hline Displays no errors in spelling, \\
punctuation, grammar, and sentence & Answers are comprehensive & Answers are substantial & Exemplary \\
structure & and accurate. Key ideas are & and complete & \\
& clearly stated, explained and & & \\
& well supported & & \\
\hline
\end{tabular}

A significant relationship between profile and listening skills of college freshmen were analy zed using Spearman's rhoand Pearson's r coefficient formulae.

The statistical tool used in the above-stated problems was the Statistical Package for Social Sciences (SPSS) version 19.

\section{RESULTS AND DISCUSSION} 1. Profile of the Res pondents in terms of Sex, Course, Language Spoken at Home, Gadgets Used, and Programs Watched or Listened to.

From 315 students, 159 or 50.48 percent are males, while 156 or 49.52 are females.

As to the program of the respondents, the 24 respondents or 7.62 percent are Education students, 13 or 4.13 percent are taking up Criminology, Architecture and Nursing both have 3 respondents with 0.95 percent, 10 or 3.17 percent are Agriculture students, 111 or 35.24 percent are taking up Business Management, 8 or 2.54 percent are taking up Engineering, 26 or 8.25 percent are Industrial Technology students, 25 or 7.94 percent are enrolled in Hotel and Restaurant Management and 92 or 29.21 percent of the respondents are from the Information Technology department.

In terms of the language/s spoken at home, 242 respondents or 76.83 percent speak Tagalog at home, 64 or 20.32 percent speak both Tagalog and English at home, 6 or 1.90 percent speak one more language at home aside from Tagalog and English, and 3 or 0.95 percent of the respondents speak two more languages at home aside from Tagalog and English.

As to the Audio-Gadgets used, the 185 respondents use television which obtained rank 2, the 69 respondents use radio that made it to rank 4 , the 287 respondents use mobile phone which earned rank 1, the 96respondents use androids which earned number one rank, and 8 respondents use other gadgets that obtained the lowest rank which is 5 .

In the programs watched of listened to by respondents, the 198 respondents watch and listen to news which obtained rank 2 , the 83 respondents listen to radio which obtained rank 7 , the 88 respondents watch series which obtained rank 6 , the 73 respondents watch talk shows which obtained rank 8, the 131 respondents watch cartoons/animations which obtained rank 3, the 229 respondents listen to music/songs which obtained rank 1, the 129 respondents watch games which obtained rank 4, and 96 respondents watch talent searches which obtained rank 5.

2. Listening Skills of the Respondents in terms of Recei ving, Understanding, Remembering, Evaluating, and Responding.

\subsection{Receiving Stage}

The table below shows the receiving skills of the respondents. The score ranging from 0-7 obtained the lowest frequency with a total of 8 or 2.53 percent with a verbal interpretation of "Poor" while the score ranging from 29-35 obtained the highest frequency with a total of 150 or 47.62 percent with a verbal interpretation of "Excellent".

Table 4. Receiving Skills of the Respondents

\begin{tabular}{cccc}
\hline Scores & $\mathbf{f}$ & \% & Verbal Interpretation \\
\hline $0-7$ & 8 & 2.53 & Poor \\
$8-14$ & 9 & 2.86 & Fair \\
$15-21$ & 68 & 21.59 & Good \\
$22-28$ & 80 & 25.40 & Very Good
\end{tabular}




\section{9-35}

Total

$\mathbf{3 1 5}$

47.62

Excellent

It may be inferred that almost half of the number of respondents has successfully received and heard the message.

According to [15], "in the receiving stage, audience members must be stimulated and motivated if careful listening is to occur." At this stage, the message is only heard.[16]said that" sounds that bombard the ears are just received and not understood." [17] also added that "listening is the process of giving undivided attention to the speaker. If anyone is interrupted by distractions, it is impossible to receive the message".

\subsection{Understanding Stage}

As indicated in Table 5, the data presented is about the understanding skills of the respondents. The score ranging from 8-14 obtained the highest frequency with a total of 91 or 28.83 percent with a verbal interpretation of "Fair" while the score ranging from 29-35 obtained the lowest frequency with a total of 29 or 9.20 percent with a verbal interpretation of "Excellent."

Table 5. Understanding Skills of the Respondents

\begin{tabular}{cccc}
\hline Scores & f & \% & Verbal Interpretation \\
\hline $0-7$ & 76 & 24.13 & Poor \\
$8-14$ & 91 & 28.83 & Fair \\
$15-21$ & 76 & 24.13 & Good \\
$22-28$ & 43 & 13.85 & Very Good \\
$29-35$ & 29 & 9.20 & Excellent \\
\hline Total & $\mathbf{3 1 5}$ & $\mathbf{1 0 0}$ & \\
\hline
\end{tabular}

The findings manifest that majority of the respondents did not understand the message. Most of them obtained scores which did not even reach half of the total score.

If a listener fails to interpret the words correctly, the message is misunderstood. At the same time, [18]quoted that "even a listener has understood the words in a message, because of the differences in backgrounds and experiences, audiences sometimes make the mistake of attaching their meanings to the words of others." According to [5],"understanding skills are primarily developed through the careful pairing of relevant experience with language."
Understanding occurs when listening is deliberately combined with experience. For one thing, if a speaker does not enunciate clearly, it may be difficult to tell what the message is [19].

\subsection{Remembering Stage}

It can be gleaned on Table 6 that the score ranging from 29-35 obtained the highest frequency with a total of 235 or 74.60 percent with a verbal interpretation of "Excellent" while the score ranging from 0-7 obtained the lowest frequency with a total of 3 or 0.95 percent with a verbal interpretation of "Poor."

Table 6. Remembering Skills of the Respondents

\begin{tabular}{cccc}
\hline Scores & F & \% & Verbal Interpretation \\
\hline $0-7$ & 3 & 0.95 & Poor \\
$8-14$ & 5 & 1.59 & Fair \\
$15-21$ & 31 & 9.84 & Good \\
$22-28$ & 41 & 13.02 & Very Good \\
$29-35$ & 235 & 74.60 & Excellent \\
\hline Total & $\mathbf{3 1 5}$ & $\mathbf{1 0 0}$ &
\end{tabular}

From the table, it may be observed that the generality of the respondents had excellent remembering skills. They had the ability to remember names, places, and events.
The authors in [20]cited that "although remembering stage is wholly dependent on the ability of an individual to decipher meaning from the message and evaluation of it, a listener will attempt to retain all or bits 
and pieces of the message." [11] emphasized that this retention process prepares the brain to recall information rapidly like names, places, events over the short period required to respond to the message. Remembering begins with listening; if anyone cannot remember anything that was said, he or she might not have been listening effectively.According to [21],"an individual tends to remember events that matter to him."

\subsection{Evaluating Stage}

Table 7 shows that the score ranging from 8-14 obtained the highest frequency with a total of 78 or 24.76 percent with a verbal interpretation of "Fair" while the score ranging from 22-28 and 29-35 obtained the lowest frequency with a total of 49 or 15.56 percent with a verbal interpretation of "Very Good" and "Excellent".

Table 7. Evaluating Skills of the Respondents

\begin{tabular}{cccc}
\hline Scores & F & \% & Verbal Interpretation \\
\hline $0-7$ & 70 & 22.22 & Poor \\
$8-14$ & 78 & 24.76 & Fair \\
$15-21$ & 69 & 21.90 & Good \\
$22-28$ & 49 & 15.56 & Very Good \\
$29-35$ & 49 & 15.56 & Excellent \\
\hline Total & $\mathbf{3 1 5}$ & $\mathbf{1 0 0}$ & \\
\hline
\end{tabular}

It may be reflected on the table that majority of the respondents have difficulty in the evaluating stage. They failed to draw inferences, analyze information, and assign meanings to the message.

According to [22],"a great deal of critical listening takes place in the evaluating stage. The listener assigns meanings to the message, draws inferences, takes an overview of the message, and seeks accuracy of information and pieces of evidence". Often, the listener is disturbed by previous experiences, beliefs, and emotions, and these often come by way of an evaluation process. The authors in [23] confirmed this principle as they cited "that this stage is the process of critically analyzing information to determine how truthful, authentic, or believable the message is." When the listener evaluates effectively, he or she carefully examines the information he or she has received so that conclusions are based on accurate facts. Evaluation of a message is not a solely critical analysis of the message, but it also entails evaluating perceptions of the message and the messenger [24]. [25]said that "a person's experiences greatly affect how he evaluates things around him."

\subsection{Responding Stage}

Given the preceding, Table 8 shows the responding skills of the respondents. The score ranging from 0-7 obtained the highest frequency with a total of 99 or 31.43 percent with a verbal interpretation of "Poor" while the score ranging from 22-28 obtained the lowest frequency with a total of 44 or 13.97 percent with a verbal interpretation of "Very Good."

Table 8. Responding Skills of the Respondents

\begin{tabular}{cccc}
\hline Scores & F & \% & Verbal Interpretation \\
\hline $0-7$ & 99 & 31.43 & Poor \\
$8-14$ & 62 & 19.68 & Fair \\
$15-21$ & 58 & 18.41 & Good \\
$22-28$ & 44 & 13.97 & Very Good \\
$29-35$ & 52 & 16.51 & Excellent \\
\hline Total & $\mathbf{3 1 5}$ & $\mathbf{1 0 0}$ & \\
\hline
\end{tabular}

The same observation may be noted on the table that majority of the respondents had difficulty in responding stage. They failed to give feedback to the message being heard.

According to [26], "the responding stage is where a listener completes the process of listening by giving feedback to the speaker." Steinberg elaborated that feedback is a prerequisite for efficient listening. It consists of all the verbal and nonverbal messages that are consciously or unconsciously sent to the speaker as a response to the message. The importance of feedback is that it is the way the communicator knows an audience has sensed (heard) 
the message, understood, interpreted, and evaluated it - in other words, the audience has been listening. [27] also reiterated that at this stage, the audience response shows an understanding of and feelings about the message. The speaker sees whether the message is understood as intended or whether it should be restated or clarified. Also, responding is providing observable feedback to a sender's message.

\section{Relationship between the Profile of the Students and their Listening Skills.}

As shown in Table 9, each variable was described among the profile variables correlated, and all variables have no correlation coefficients thatfall under the level of significance of .05. Hence, the majority of the profile variables are found significantly related to their listening skills. The analysis found enough evidence to reject the hypothesis of the study. Hence, there is a significant relationship between the profile of the respondents and their listening skills.

According to [28],"men and women have different listening expectations and needs that may account for their different competencies." While men frequently engage in conversations about sports events, stock market reports, and fishing trips, women are more likely to be discussing relationships, personal experiences, or health-related topics. This gender-based selective attention further distinguishes listening behavior between the two groups. Also, men tend to engage in other activities while listening; women are more likely to focus their complete attention on the speaker. On the contrary, [29] reiterated that "gender or sex has nothing to do with a person's listening skills."

Table 9. Relationship between the Profile of the Students and their Listening Skills

\begin{tabular}{|c|c|c|c|c|c|c|c|}
\hline & & Receiving & Understanding & Responding & Evaluating & Remembering & $\begin{array}{c}\text { Listening } \\
\text { Skills }\end{array}$ \\
\hline \multirow{3}{*}{ Sex } & $\begin{array}{l}\text { Correlation } \\
\text { Coefficient }\end{array}$ & .027 & $.216^{* *}$ & $.151 * *$ & $.261 * *$ & $.290 * *$ & $.256^{* *}$ \\
\hline & Sig. (2-tailed) & .637 & .000 & .007 & .000 & .000 & .000 \\
\hline & $\mathrm{N}$ & 315 & 315 & 315 & 315 & 315 & 315 \\
\hline \multirow{3}{*}{ Course } & $\begin{array}{l}\text { Correlation } \\
\text { Coefficient }\end{array}$ & $.231 * *$ & $-.177 * *$ & $.133^{*}$ & $-.246^{* *}$ & $-.265 * *$ & $-.148 * *$ \\
\hline & Sig. (2-tailed) & .000 & .002 & .018 & .000 & .000 & .009 \\
\hline & $\mathrm{N}$ & 315 & 315 & 315 & 315 & 315 & 315 \\
\hline \multirow{2}{*}{ LSAH \# } & $\begin{array}{l}\text { Correlation } \\
\text { Coefficient }\end{array}$ & .077 & $.168 * *$ & $.164 * *$ & $.167 * *$ & $.154 * *$ & $.184 * *$ \\
\hline & Sig. (2-tailed) & .176 & .003 & .003 & .003 & .006 & .001 \\
\hline \multirow{2}{*}{ BGadgets \# } & Sig. (2-tailed) & .026 & .008 & .150 & .015 & .021 & .002 \\
\hline & $\mathrm{N}$ & 315 & 315 & 315 & 315 & 315 & 315 \\
\hline \multirow{3}{*}{ TV Shows } & $\begin{array}{l}\text { Correlation } \\
\text { Coefficient }\end{array}$ & $.209 * *$ & $.208 * *$ & $.123^{*}$ & $.209 * *$ & $.207 * *$ & $.252 * *$ \\
\hline & Sig. (2-tailed) & .000 & .000 & .029 & .000 & .000 & .000 \\
\hline & $\mathrm{N}$ & 315 & 315 & 315 & 315 & 315 & 315 \\
\hline
\end{tabular}

Likewise, reforming of the teaching method is also an important aspect to improve the quality of professional course teaching and developing students' specialty ability [30].Its main direction lies in the raising study interest in the course, opening the students' intelligence and developing an accurate method so that the students can put forth problems, analyze problems and solve problems by themselves.
Furthermore, according to [31],"spoken language affects more than learners' communication and their acquisition literacy. It also affects their capacity to learn and think of themselves, their social and emotional development, their ability to plan, organize, negotiate, and emphasize".

Today, people not only listen to music via standard broadcast signal radio and platforms based on internet or 
satellite, but they bring $\mathrm{Cds}$ and portable music players into the vehicle in increasing numbers According to [15], "poor listening skill is the effect of avoiding difficult material on TV or radio". When the topic is complicated or includes technical terms, poor listeners immediately tune out. Periodically, one should attend professional training sessions or watch challenging television programs to practice listening skills. Also, an individual usually avoids materials that are difficult to comprehend [32].

\section{CONCLUSIONS AND RECOMMENDATIONS}

The focus of this study is to determine [33] the listening skills of the students based on the stages are receiving, understanding, remembering, evaluating, and responding [11].

The researcher found out thatmost respondents, regardless of their profile, use their listening skill in listening to Tagalog music during the day through a medium (mostly mobile phones) accessible to them at all times. However, most respondents have only an average listening skill proved that they have a limited listening capability that needs to be properly addressed. Similarly, the respondents' academic performance could be affected if their listening skills would not be improved. Hence, intervention programs or activities that could enhance the listening competence of NEUST freshmen in learning the English language is needed and shall be regularly practiced. Additionally, research studies with wider respondents should be done to evaluate and investigate the effectiveness [34] of other mobile applications in improving the listening skills of the students.

\section{ACKNOWLEDGMENT}

I am very grateful to Dr. Jesster P. Eduardo and Dr. Gener S. Subia for editing and enhancing the content of my paper. Also, they both worked for the publication of this research.

\section{REFERENCES}

[1] Moreno, R. (2011). Words for Working: Professional and Academic English for International Business and Economics.

Retrieved

from

https://books.google.com.ph/books?is bn=1285159454 on May 30, 2016.

[2] Ladera, H. et. al (2013). The New Dimensions in Learning English. Retrieved from https://books.google.com/books?is bn $=0891284915$ on May 30, 2016.
[3] Fulcher, G. (2014). Testing Second Language Speaking.Retrieved from https://books.google.com/books ?is bn $=0702172618$ on May 30, 2016.

[4] Mangahis, J. (2011). Macro-skills in Filipinology.Retrieved from e-journals.org.ph.

[5] Barclay, L. (2011). Learning To Listen/Listening To Learn: Teaching Listening Skills to Students with Visual Impairments. Sucat, Manila: Anvil Publishing, Inc.

[6] Downs, L. (2008). Listening Skills Training.Retrieved from

https ://books.google.com.ph/books ?is bn=15144333 on May 30, 2016.

[7] Reynolds, C., Janzen, E. (2007). Encyclopedia of Special Education: A Reference for the Education of Children, Adolescents, and Adults with Disabilities and Other Exceptional Individuals. Volume 1.Retrieved from https://books.google.com.ph/books ?is bn=1285969693 on May 30, 2016.

[8] Hoppe, M. (2011). Center for Creative Leadership (CCL). Quezon City: Lorimar Publishing, Incorporated.

[9] Santos, B. (2008). AngWikang Filipino saLoob at Labas Akademya'tBansa. Retrieved from https://books.google.com/books?is bn $=9716350155$ on May 5, 2017.

[10] Janusik L.A, Wolvin, A (2007). Listening: Processes, Functions and Competency. Mississippi, USA: JW Publishing, Incorporated.

[11] Wrench, R. et.al (2011). Public Speaking: Practice and Ethics. Volume 1.Retrieved from https://books.google.com.ph/books?is bn $=1444359371$ on June 3, 2016.

[12] Weiten, W. (2012). Themes and Variations.Retrieved from

https://books.google.com/books? is bn $=1562865021$ on May 30, 2016.

[13] M. L. Patten. Understanding Research Methods. Pyrczak Publishing: U.S.A., 2002

[14] Subia, G., Salangsang, L. and Medrano, $H$. (2018).Attitude and Performance in Mathematics I of Bachelor of Elementary Education Students: A Correlational Analysis. American Scientific Research Journal for Engineering, Technology, and Sciences (ASRJETS) (2018) Volume 39, No 1, pp 206-213.

[15] Hamilton, C. (2014). Cengage Advantage Series: Essentials of Public Speaking. Retrieved from 
https://books.google.com/books?is bn $=0702177148$ on July 8, 2016.

[16] Flores, E. (2014). Academic Journals in Listening.Retrieved from www.acade micjournals .org/journal/IJEL/article-fulltext-pdf/13202B746106 on May 6, 2017.

[17] Achua, C., \&Lussier, R. (2015). Leadership: Theory, Application and Skill Development p. 189. Retrieved from

https://books.google.com/books?id=gfk6AQAAMAA J on May 5, 2016.

[18] Attias, R. (2011). The Death of Language. New Delhi, India: APH Publishing Corporation.

[19] Tayao, M. (2008). A Lectal Description of Phonological Features of Philippine English.Retrieved from www.acade mic journals .org/journal/IJEL/artic lefull-text-pdf/13202B746106 on May 7, 2017.

[20] Smith, T., Busler, M. (2012). The Key to Survival: Interpersonal Communication, Fourth Edition. Retrieved from https://books.google.com.ph/books?is bn $=1305537254$ on June 3, 2016.

[21] Molina, R. (2009). SandosenangKuya. Retrived from https://books.google.com/books?id=91dAAAAAMA AJ on May 7, 2017.

[22] Sen, L. (2007). Communication Skills.p.36. Chicago, Illinois: Kaplan Publishing.

[23] Solomon, D., \&Theiss, J. (2013). Interpersonal Communication: Putting Theory Into Practice. Retrieved from https://books.google.com.ph/books?is bn=1317346769 on June 8, 2016.

[24] Livingston, R. (2010). Advanced Public Speaking: Dynamics and Techniques. Retrieved from https://books.google.com.ph/books?is bn $=0398085676$ on May 30, 2016.

[25] Abueg, E. (2007). SaBagwisngSining: MgaNaunangManunulatng Cavite. Retrieved from https://books.google.com/books?is bn=9719259019 on May 6, 2017.

[26] Steinberg, S. (2007). An Introduction to Communication Studies.p. 77.Retrieved from https://books.google.com/books?is bn $=1317901649$ on May, 30, 2016.

[27] Cleary, S. (2008). Communication: A Hands-on Approach p.75. Retrieved from https://books.google.com.ph/books?is bn $=0071749144$ on May 30, 2016.
[28] Brownell, J. (2015).Listening: Attitudes, principles, and skills, sixth edition. https://www.researchgate.net/publication/326393074_ Listening_Attitudes_principles_and_skills_sixth_editi on

[29] Madula, R. (2016). Kuwentong Buhayng Isang Pambansa-Demokratikong Rebolusyonaryong Baklasa Rehiyonng Katimugang Mindanao (A Life Story of a Gay National-Democratic. Retrieved from journals.upd.edu.ph on May 7, 2017.

[30] Zhang, C., Zhang L. (2011). Engineering Education and Management.Volume 2.Retrieved from https://books.google.com/books? is bn $=1134659377$ on May 30, 2016.

[31] Locke, J. (2009). Two Treaties on Government: A Translation Into Modern English. Diliman, Quezon City: Precious Hearts Publishing.

[32] Villafuerte, P. (2007). Ang Gurong Manunulat/ Ang Manunulatna Guro: Dukalng Pagkamalikhain At Sosyo-Politikalna Bansa. Retrieved from pnuresearchportal.org on May 7, 2017.

[33] Eduardo, J. (2018). Indigenous Peoples' Rights Act (IPRA) of 1997: A Standpoint from Selected Higher Education Institutions in Nueva EcijaAfter 20 Years. Journal of Progressive Research in Social Sciences, 8(1), 595-613. Retrieved from http://www.scitecresearch.com/journals/index.php/jprs s/article/view/1547

[34] Subia, G.S. (2018).Comprehensible Technique in Solving Consecutive Number Problems in Algebra. Journal of Applied Mathematics and Physics, 6,447457. https://doi.org/10.4236/jamp.2018.63041 